\title{
JURNAL PENDIDIKAN GEOGRAFI \\ PENGEMBANGAN KAWASAN SITU GEDE SEBAGAI OBJEK WISATA ANDALAN KOTA TASIKMALAYA
}

\author{
Riki Ridwana ${ }^{1}$, Enok Maryani ${ }^{2}$, Nandi ${ }^{3}$ \\ 1,2,3Departemen Pendidikan Geografi, Universitas Pendidikan Indonesia \\ 1rikiridwana@upi.edu , ${ }^{2}$ enokmaryani@upi.edu , ${ }^{3}$ nandi@upi.edu
}

\begin{abstract}
The Situ Gede area has the opportunity to provide benefits for the Regional Government of Tasikmalaya City and the community. The method used is descriptive method. The study population was the entire Situ Gede area with samples of the Linggajaya Village and Mangkubumi Village, Mangkubumi District, Tasikmalaya City. The sample consisted of 81 residents, 100 tourists, and 7 tourism managers. Data analysis techniques use percentages, appreciation and weighting, and SWOT analysis. The results showed that the Situ Gede area had a high potential for tourist attractions, while the availability of tourist facilities and infrastructure was low. Then, the level of accessibility is moderate. The researcher recommends to improve the quality of accessibility and improve tourism facilities consisting of information and security facilities.
\end{abstract}

Keywords: tourism potential, obstacles of tourism development, tourism development strategy

\begin{abstract}
ABSTRAK
Kawasan Situ Gede memiliki peluang untuk memberikan keuntungan bagi Pemerintah Daerah Kota Tasikmalaya dan masyarakat. Metode penelitian yang digunakan adalah metode deskriptif. Populasi penelitian adalah seluruh kawasan Situ Gede dengan sampel wilayah Kelurahan Linggajaya dan Kelurahan Mangkubumi Kecamatan Mangkubumi Kota Tasikmalaya. Sampel terdiri dari 81 orang penduduk, 100 orang wisatawan, dan 7 orang pengelola pariwisata. Teknik analisis data menggunakan persentase, pengharkatan dan pembobotan, dan analisis SWOT. Hasil penelitian menunjukkan bahwa kawasan Situ Gede memiliki potensi atraksi wisata yang tinggi, Sedangkan pada ketersediaan sarana dan prasarana wisata rendah. Lalu, tingkat aksesibilitas sedang. Peneliti merekomendasikan untuk memperbaiki kualitas aksesibilitas dan meningkatkan fasilitas wisata yang terdiri dari sarana informasi dan keamanan.
\end{abstract}

Kata kunci: potensi pariwisata, kendala pengembangan pariwisata, strategi pengembangan pariwisata.

\section{PENDAHULUAN}

Pariwisata menurut Pitana dan Gayatri (2005: 3) telah menjadi salah satu industri terbesar di dunia, dan merupakan andalan utama dalam menghasilkan devisa di berbagai negara. Meningkatnya peranan pariwisata dalam pembangunan ekonomi tidak terlepas dari perencanaan pariwisata itu sendiri. Perencanaan pariwisata sangat penting dilakukan karena saat ini dan di masa depan akan terus terjadi pergeseran pasar wisata. Motif, minat, selera, tuntutan, dan perilaku wisatawan terus-menerus berubah dan hal ini perlu direspons dengan tepat, Damanik dan Weber (2006: 25).

Pertumbuhan kepariwsataan yang tidak terkendali sebagai akibat dari perencanaan yang tidak baik, pasti akan menimbulkan dampak yang tidak baik dan tentunya akan tidak menguntungkan 
semua pihak. Bangunan Hotel yang menjulang tinggi, poster iklan yang merusak pemandangan dan lingkungan, pembuangan sampah yang tidak pada tempatnya, pengotoran pantai yang tidak terkendali sebagai akibat banyaknya wisatawan yang berkunjung, semuanya dapat saja terjadi sebagai akibat dari perencanaan yang tidak baik, Yoeti (2008: 47).

Di sinilah pentingnya ide dasar pembangunan berkelanjutan. Ide dasar pembangunan berkelanjutan menurut Damanik dan Weber (2006: 25) adalah kelestarian sumberdaya alam dan budaya. Ide-ide itu kemudian diturunkan ke dalam konsep pariwisata berkelanjutan. Artinya adalah pembangunan semberdaya (atraksi, aksesibilitas, amenitas) pariwisata yang bertujuan untuk memberikan keuntungan optimal bagi pemangku kepentingan (stakeholders) dan nilai kepuasan optimal bagi wisatawan dalam jangka panjang.

Waduk Situ Gede yang cenderung lebih dikenal dari aspek wisata, memiliki peluang untuk memberikan keuntungan bagi pemangku kepentingan antara lain Dinas Kebudayaan dan Pariwisata Kota Tasikmalaya dan masyarakat sekitar yang menggantungkan hidupnya di kawasan wisata Situ Gede, apabila dikembangkan dengan perencanaan matang. Pengelolaan kawasan ini telah ditetapkan dalam bentuk peraturan Walikota Tasikmalaya No 9 tahun 2006 tentang pemanfaatan Sumber Daya Alam Di Objek Daya Tarik Wisata Situ Gede. Situ Gede terletak di Kelurahan Mangkubumi dan Kelurahan Linggajaya Kecamatan Mangkubumi, sekitar 2,5 sampai $3 \mathrm{~km}$ ke arah barat daya dari pusat Kota Tasikmalaya.

Berdasarkan Rencana Tata Ruang Wilayah Provinsi (RTRWP) Jawa Barat Tahun 2002-2010, Kota Tasikmalaya termasuk dalam kawasan andalan di
Priangan Timur dan sekitarnya. Dalam kawasan andalan ini, Tasikmalaya berperan sebagai Kota Pusat Kegiatan Wilayah (PKW). Dengan demikian kota ini menjadi kawasan perkotaan yang berfungsi untuk melayani kegiatan skala provinsi atau beberapa kabupaten/kota yang ada disekitarnya.

Seperti yang diutarakan di atas, bahwa Kota Tasikmalaya termasuk ke dalam salah satu kawasan andalan yang diarahkan menjadi pusat pengembangan wilayah dengan pemanfaatan sektor unggulannya. Mengingat keberadaan Kota Tasikmalaya dengan kelengkapan sarana dan prasarananya yang diproyeksikan untuk dapat dijadikan sebagai wilayah yang dapat memberikan pengaruh positif dalam perkembangan wilayah dipandang sangat strategis. Wilayah Kota Tasikmalaya yang strategis akan sangat menunjang terhadap berbagai pemanfaatan sektor unggulan yang telah ada antara lain perdagangan dan industri. Dari sekian banyak sektor unggulan yang ada, salah satunya adalah industri pariwisata.

Salah satu diantara industri pariwisata di Kota Tasikmalaya adalah kawasan wisata Situ Gede. Kawasan tersebut adalah sebagai objek wisata satusatunya yang dikelola langsung oleh pemerintah Kota Tasikmalaya, berpotensi menjadi objek wisata andalan Kota Tasikmalaya yang dapat menarik banyak wisatawan sehingga menyediakan lapangan pekerjaan yang luas dan beragam serta menjadi sumber kehidupan bagi masyarakat setempat. Selain itu letak objek wisata Situ Gede yang strategis yang tidak jauh dari pusat kota idealnya menjadi pemicu sehingga objek wisata ini mampu meningkatkan pendapatan daerah. Akan tetapi dari sekian banyak peluang yang dimiliki, kawasan Situ Gede belum optimal memberikan kontribusi baik terhadap 
peningkatan pendapatan daerah maupun perekonomian masyarakat sekitar.

Dengan demikian perlu dilakukan penelitian agar diketahui potensi pariwisata dan kendala yang mungkin timbul dalam pengembangan objek wisata Situ Gede. Selain itu dengan dilakukan penelitian agar diketahui strategi pengembangan yang paling akurat untuk mengembangkan Situ Gede sebagai objek wisata andalan di Kota Tasikmalaya yang diharapkan dapat berdampak pada peningkatan pendapatan daerah.

\section{METODE PENELITIAN}

Penelitian ini menggunakan metode deskriptif. Tujuan penulis menggunakan metode deskriptif adalah untuk mengungkapakan berbagai potensi dan kendala dalam pengembangan kawasan wisata Situ Gede. Selain itu juga bermaksud untuk membuat strategi pengembangan kawasan Situ Gede sehingga menjadi objek wisata andalan Kota Tasikmalaya.

Populasi dalam penelitian ini meliputi populasi wilayah yaitu seluruh kawasan Situ Gede Kelurahan Linggajaya dan Kelurahan Mangkubumi, dapat dilihat pada gambar 1. Populasi manusia yaitu penduduk sekitar yang berada di sekitar objek wisata, pengelola, dan pengunjung objek wisata (wisatawan). Pengambilan sampel pada penelitian ini terdiri dari dua macam, yaitu: sampel wilayah yang diambil adalah objek wisata yang berada di kawasan wisata Situ Gede yaitu kelurahan Linggajaya dan kelurahan Mangkubumi. Sampel responden, pada penelitian ini terbagi dalam tiga kelompok, yaitu sampel responden penduduk, sampel responden wisatawan, dan sampel responden pengelola pariwisata.

Dalam menentukan besarnya sampel penduduk digunakan rumus yang dikemukakan oleh Dison dan B.
Leach dalam Tika (2005: 25). Data jumlah penduduk yang termasuk pada sampel di daerah penelitian yaitu mencakup Kelurahan Linggajaya dan Kelurahan Mangkubumi. Untuk data selengkapnya dapat dilihat pada tabel 1 .

Berikut rumus yang digunakan dalam penentuan sampel:

$n=\left[\frac{Z x V}{C}\right]^{2}$

Dimana:

$\mathrm{n}:$ Jumlah sampel

$\mathrm{Z}$ : Confidence level, nilai convidence level $95 \%$ adalah 1,96

$\mathrm{V}$ : Variabel yang dapat diperoleh dengan rumus:

$\mathrm{V}=\sqrt{p(100-p)}$

$\mathrm{P}=$ Persentase karakteristik sampel yang dianggap benar

$\boldsymbol{n}^{\prime}=\frac{\boldsymbol{n}}{1+\left[\frac{n}{N}\right]}$

$\mathrm{C}=$ Confidence limit $/$ Batas kepercayaan (\%)

$\mathrm{n}^{\prime}=$ Jumlah sampel yang telah dikoreksi

$\mathrm{n}=$ Jumlah sampel yang telah dihitung berdasarkan rumus (1)

\section{$P=\frac{\text { Jumlah Kepala Keluarga }}{\text { Jumlah Penduduk }} \times 100 \%$}

$\mathrm{N}=$ Jumlah populasi (kepala keluarga)

$$
P=\frac{8.122}{26.546} x 100
$$

$$
\begin{aligned}
\mathrm{P} & =30,59 \% \\
V & =\sqrt{P(100-P)} \\
& =\sqrt{30,59(100-30,59)} \\
& =\sqrt{2123,2519} \\
& =46.08
\end{aligned}
$$




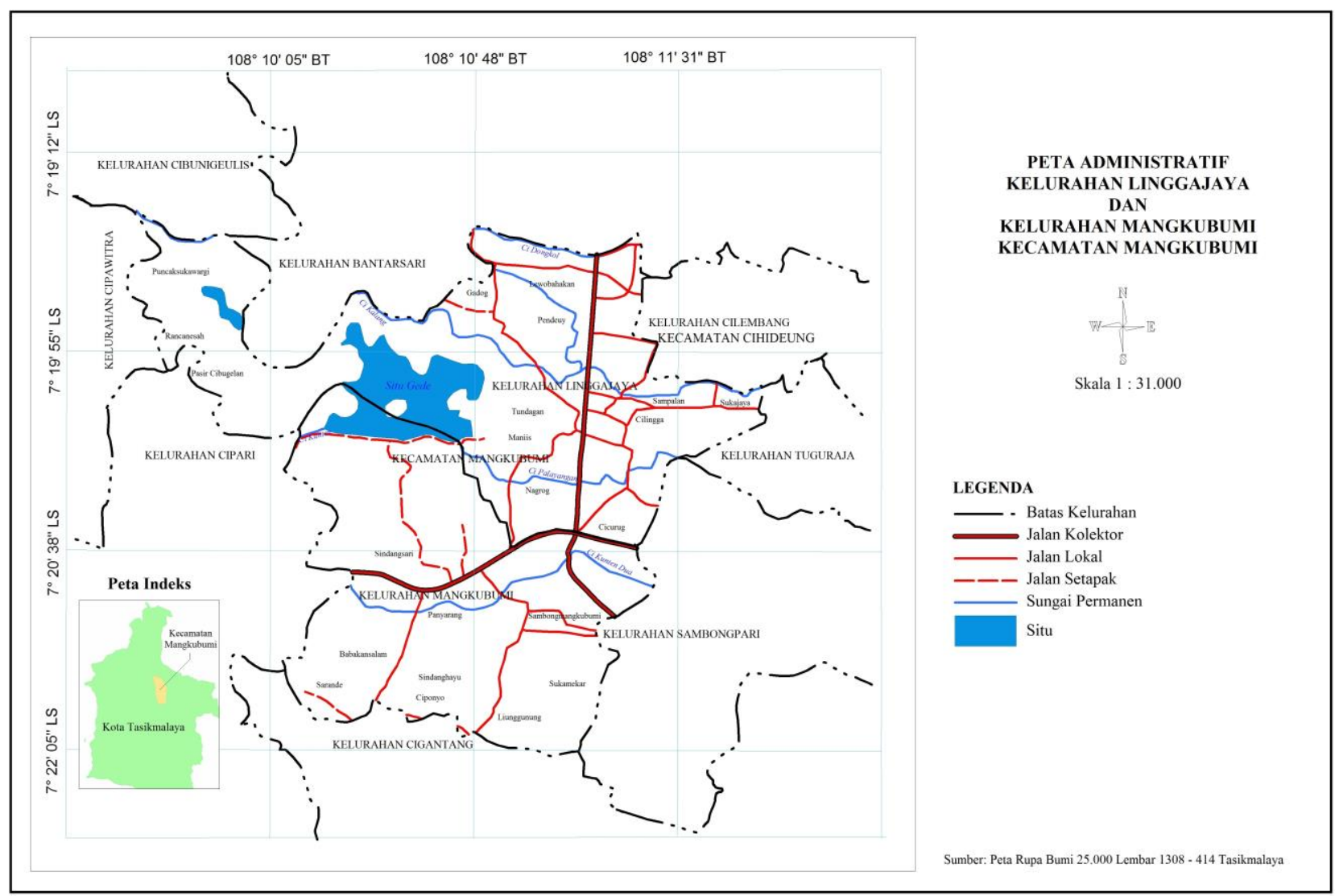

Gambar 1. Lokasi Penelitian

Tabel 1. Sampel Responden Penduduk

\begin{tabular}{ccccc}
\hline No. & Kelurahan & Jumlah Penduduk & Jumlah KK & $\begin{array}{c}\text { Jumlah } \\
\text { Sampel }\end{array}$ \\
\hline 1. & Linggajaya & 14.129 & 4.155 & 41 \\
\hline 2. & Mangkubumi & 12.417 & 3.967 & 40 \\
\hline & Jumlah & $\mathbf{2 6 . 5 4 6}$ & $\mathbf{8 . 1 2 2}$ & $\mathbf{8 1}$ \\
\hline
\end{tabular}

$n=\left[\frac{Z x V}{C}\right]^{2}$

$n=\left[\frac{1,96 \times 46,08}{10}\right]^{2}$

$=[9.03]^{2}$

$=81,54$

$n=\frac{n}{1+\left(\frac{n}{n}\right)}$

$=\frac{81,54}{1+\left(\frac{81,54}{8.122}\right)}$

$=\frac{81,54}{1,01}$

$=80.7$

$=81$ (dibulatkan)
Jumlah sampel yang diambil dalam penelitian ini sebanyak 81 responden. Untuk menentukan sampel dari masing-masing kelurahan secara proporsional, digunakan formula dari Soepono (Nuryeti, 2006: 39) sebagai berikut:

$N=\frac{P^{\prime}}{P} x n$

$\mathrm{N}$ : Jumlah sampel KK tiap kelurahan

$\mathrm{P}^{\prime}$ : Jumlah populasi KK tiap kelurahan

$\mathrm{P}$ : Jumlah populasi keseluruhan

$\mathrm{n}$ : Jumlah seluruh sampel 
Berdasarkan hasil perhitungan dengan teknik ini, maka jumlah sampel tiap kelurahan adalah sebagai berikut:

Kelurahan Linggajaya (41 orang) dan Kelurahan Mangkubumi (40 orang):

$$
\begin{aligned}
& \frac{4.155}{8.122} \times 81=41 \\
& \frac{3.967}{8.122} \times 81=40
\end{aligned}
$$

Sampel wisatawan dalam penelitian ini adalah wisatawan yang mengunjungi daerah penelitian dalam waktu yang sama dengan peneliti. Untuk mendapatkan banyaknya responden wisatawan, maka penentuan sampel dala penelitian ini digunakan rumus Slovin (Umar, 2008: 108) sebagai berikut:

$n=\frac{N}{1+N e^{2}}$

Dimana:

n : Ukuran sampel

$\mathrm{N}$ : Ukuran populasi

e : Tingkat kesalahan pengambilan sampel yang masih dapat ditolerir

Dari jumlah populasi tersebut dengan tingkat kesalahan sebesar 10\%, maka dengan rumus diatas diperoleh sampel sebesar:

$$
n=\frac{19.875}{1+19.875\left(0,1^{2}\right)}=99,88=100 \text { orang }
$$

Berdasarkan hasil perhitungan diatas diperoleh jumlah sampel untuk wisatawan sebesar 100 orang.

Penarikan sampel responden pengelola yaitu dari pengelola kawasan objek wisata Situ Gede yang terdapat di Dinas Kebudayaan dan Pariwisata Kota Tasikmalaya.

Teknik analisis data yang digunakan dalam penelitian ini adalah persentase, pengharkatan (scoring) dan pembobotan (weighting), dan analisis SWOT. Penjelasannya dapat disimak di bawah ini.

\section{Analisis Persentase}

Melakukan analisis persentase untuk mengetahui kecenderungan responden dan fenomena-fenomena di lapangan dengan menggunakan rumus:

$$
P=\frac{f}{n} x 100 \%
$$

Keterangan:

$P \quad=$ Persentase

$f \quad=$ Frekuensi dari setiap alternatif jawaban yang dipilih

$n \quad=$ Jumlah seluruh frekuensi alternatif jawaban yang jadi pilihan $100=$ konstanta

Setelah dilakukan perhitungan maka hasil persentase tersebut diklasifikasikan dengan kategori sebagai berikut:

Tabel 2. Persentase

\begin{tabular}{cll}
\hline No & Persentase & \multicolumn{1}{c}{ Keterangan } \\
\hline $\mathbf{1}$ & $0 \%$ & Tidak seorangpun \\
\hline $\mathbf{2}$ & $1 \%-24 \%$ & Sebagian kecil \\
\hline $\mathbf{3}$ & $25 \%-49 \%$ & $\begin{array}{l}\text { Hampir } \\
\text { setengahnya }\end{array}$ \\
\hline $\mathbf{4}$ & $50 \%$ & Setengahnya \\
\hline $\mathbf{5}$ & $51 \%-74 \%$ & Sebagaian besar \\
\hline $\mathbf{6}$ & $75 \%-99 \%$ & $\begin{array}{l}\text { Hampir } \\
\text { seluruhnya }\end{array}$ \\
\hline $\mathbf{7}$ & $100 \%$ & \begin{tabular}{l} 
Seluruhnya \\
\hline
\end{tabular} \\
& \multicolumn{3}{c}{ Sumber: Arikunto (1990: 57) }
\end{tabular}

\section{Pengharkatan (Scoring) dan Pembobotan (Weighting)}

Peringkat masing-masing parameter diurutkan berdasarkan kategori yaitu harkat 5 untuk nilai tertinggi dengan kelas sangat tinggi untuk parameter yang memenuhi semua kriteria yang dijadikan indikator, harkat 4 untuk kelas tinggi, harkat 3 untuk kelas sedang, harkat 2 untuk kelas rendah, dan harkat 1 untuk kelas sangat rendah. 
Kriteria pengharkatan diperoleh melalui adaptasi dari beberapa sumber yang relevan.

Di dalam penelitian ini ditentukan bahwa bobot terbesar untuk aspek atraksi wisata adalah 35 dan terkecil adalah 7. Bobot terbesar untuk aspek sarana dan prasarana adalah 40 dan terkecil adalah 8. Bobot terbesar untuk aspek aksesibilitas adalah 25 dan terkecil adalah 5. Nilai tiap kriteria dalam penelitian ini ditetapkan dengan scoring, skor terendah untuk keseluruhan aspek yaitu 1 dan tertinggi 5 . Sedangkan skor berkisar antara 1 sampai 5 dimana besarnya nilai masing-masing kriteria merupakan jumlah dari nilai tiaptiap parameter yang berkaitan. Setelah dilakukan pengharkatan terhadap potensi kawasan wisata langkah berikutnya adalah melakukan analisis terhadap pengembangan kawasan wisata yang berpatokan pada harkat dan parameter-parameter yang telah ditentukan. Analisis ini untuk mengetahui seberapa besar tingkat dukungan aspek-aspek tersebut terhadap pengembangan kawasan Situ Gede.

\section{Analisis SWOT}

Analisis SWOT memungkinkan untuk mengembangkan model strategi yang didasarkan pada infromasi yang telah dikumpulkan. Analisis SWOT mengasumsikan bahwa organisasi akan mencapai strategi yang sukses dengan memaksimalkan kekuatan dan peluang serta meminimalkan kelemahan dan hambatan (Ukas, 2006: 215).

Berdasarkan hasil analisis data sebelumnya, selanjutnya dilakukan analisis mengetahui strategi pengembangan Kawasan Situ Gede sebagai objek wisata andalan di Kota Tasikmalaya. Analisis pengembangan ini dilakukan dengan menggunakan metode analisis SWOT (Strength, Weakness, Opportunity, dan Treath). Tujuan dari penggunaan metode analisis ini adalah untuk mengkaji potensi geografis yang mendukung keberadaan wisata serta berusaha mempertemukan seluruh aspek kekuatan, kelemahan, peluang, dan ancaman yang terdapat di kawasan Situ Gede. Formula SWOT dijadikan sebagai dasar pertimbangan dalam memberikan masukan, petunjuk, dan pengarahan bagi pengambilan keputusan atau kebijakan untuk mengkaji potensi kawasan Situ Gede sebagai objek wisata andalan Kota Tasikmalaya.

Matriks SWOT disusun berdasarkan hasil skoring dan pembobotan yang disusun setelah menginventarisir faktor-faktor strategis yang dianggap dapat mewakili unsurunsur yang dinilai dalam pengembangan kawasn wisata Situ Gede. Nilai yang diberikan kepada masing-masing faktor berurutan dari nilai tertinggi 5 (sangat baik) sampai dengan nilai terendah 1 (buruk). Setelah masing-masing unsur SWOT diberikan penilaian, kemudian unsur-unsur tersebut dihubungkan keterkaitannya untuk memperoleh beberapa alternatif strategi. Adapun desain penelitian dapat dilihat pada gambar 2 .

\section{HASIL DAN PEMBAHASAN \\ Potensi Atraksi Wisata Kawasan Situ Gede}

Kawasan Situ Gede memperoleh total bobot 203 dengan mean atau ratarata 29, sehingga dengan demikian kawasan ini termasuk dalam kategori potensi tinggi/sangat mendukung. Tingginya potensi tersebut dipengaruhi oleh banyaknya keragaman yang ada di kawasan ini baik secara alami maupun buatan. Selain bernuansa alam kawasan Situ Gede juga bernuansa budaya dan sejarah terutama pada makam yang terletak di pulau tengah Situ Gede sehingga mempengaruhi banyaknya wisatawan yang datang. 


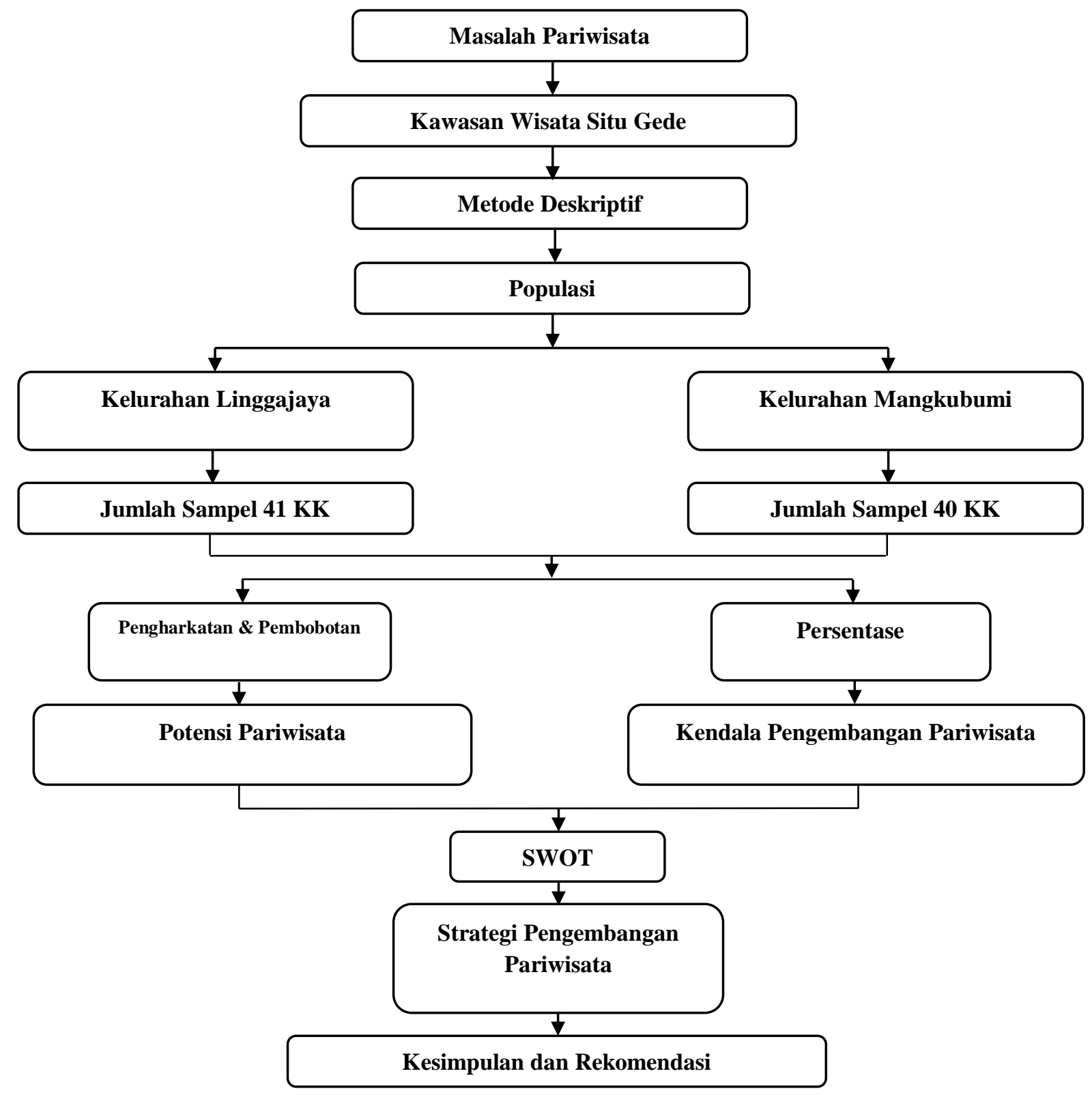

Gambar 2. Desain Penelitian

Tabel 3. Pembobotan Potensi Atraksi Wisata

\begin{tabular}{clccc}
\hline No & \multicolumn{1}{c}{ Parameter } & Bobot & Harkat & Total Bobot \\
\hline 1 & Jenis atraksi wisata & 7 & 5 & 35 \\
\hline 2 & Variasi aktivitas wisata & 7 & 5 & 35 \\
\hline 3 & Keunikan/kekhasan & 7 & 5 & 35 \\
\hline 4 & Adat Istiadat & 7 & 1 & 7 \\
\hline 5 & Cinderamata & 7 & 5 & 35 \\
\hline 6 & Event wisata & 7 & 4 & 28 \\
\hline 7 & Kesenian & 7 & 4 & 28 \\
\hline & & Jumlah & 29 & 203 \\
\hline & Mean & & & 29 \\
\hline
\end{tabular}


Potensi Sarana dan Prasarana Kawasan Situ Gede

Hasil

pembobotan

memperlihatkan bahwa kawasan Situ Gede memperoleh total bobot 144 dengan rata-rata 18. Dengan demikian kawasan ini termasuk kategori potensi rendah/kurang mendukung dalam sarana dan prasarana. Hal ini dikarenakan masih terbatasnya dana pembangunan sarana dan prasarana itu sendiri sehingga sampai dengan saat ini penyediaan sarana dan prasarana masih bertahap sesuai dengan dana yang ada. Selain itu kurang baiknya pengelolaan terhadap sarana dan prasarana yang telah tersedia terutama dalam pemeliharaan turut mempengaruhi terhadap potensi sarana dan prasarana itu sendiri.

\section{Aksesibilitas Kawasan Situ Gede}

Hasil penelitian yang disajikan dalam tabel diatas, dapat dilihat bahwa kawasan Situ Gede memperoleh total bobot 75 dan rata-rata 15, sehingga kawasan ini termasuk dalam kategori potensi sedang atau cukup mendukung. Hal ini dikarenakan kondisi jalan masuk menuju objek wisata yang kurang baik dan jauh dari jaringan transportasi umum.

\section{Kendala Pengembangan Pariwisata}

Kendala dalam pengembangan pariwisata di Kawasan Situ Gede adalah, jalannya yang rusak, belum optimalnya pada situasai keamanan, ketersediaan sarana keamanan dan sarana informasi, sarana kesehatan di lokasi kawasan wisata sebagian besar menyatakan tidak memadai, dan perlu pembenahan pada keragaman objek wisata dan sarana prasarana.

\section{Strategi Pengembangan Kawasan Situ Gede}

Berikut dijelaskan berbagai kekuatan, kelemahan, peluang, dan ancaman yang ada di kawasan objek wisata Situ Gede, yang dapat dilihat pada tabel 6 .

\section{Kekuatan - Peluang (SO)}

Mengembangkan potensi objek dan daya tarik wisata yang dimiliki kawasan Situ Gede seperti adat istiadat, wisata ziarah dan event-event wisata. Optimalisasi fungsi dan peran kelembagaan sektor pariwisata. Melakukan promosi dan pemasaran yang tepat sasaran pada wilayah-wilayah yang merupakan potensi pasar wisata yang cukup besar. Meningkatkan kuantitas dan kualitas sumber daya manusia dengan cara rekruitmen dan penyuluhan/pelatihan.

\section{Kekuatan - Ancaman (ST)}

Dilakukan upaya-upaya untuk meningkatkan dan menampilkan daya tarik dan keunikan objek dan daya tarik wisata yang di miliki kawasan Situ Gede dengan cara peningkatan fasilitas penunjang kegiatan pariwisata serta peningkatan upaya promosi dan pemasaran agar berdampak pada kunjungan wisatawan yang sangat tinggi. Dilakukan kerjasama dengan investor untuk meningkatkan kawasan Situ Gede sebagai objek wisata. Menggiatkan berbagai promosi wisata melalui kegiatan-kegiatan kepariwisatan. Meningkatkan upaya penegakkan hukum dalam rangka menangani permasalahan lingkungan sosial budaya sebagai wujud dukungan dalam pengembangan pariwisata.

\section{Kelemahan - Peluang (WO)}

Meningkatkan pengembangan dan pemeliharaan sarana dan prasarana penunjang objek wisata. Melakukan perbaikan aksesibilitas dalam rangka memberikan kemudahan bagi wisatawan untuk menuju lokasi objek wisata. Melengkapi penyediaan fasilitas pariwisata. 
Tabel 4. Pembobotan Potensi Sarana dan Prasarana

\begin{tabular}{clccc}
\hline No & \multicolumn{1}{c}{ Parameter } & Bobot & Harkat & Total Bobot \\
\hline 1 & Ketersediaan air bersih & 8 & 4 & 32 \\
\hline 2 & Akomodasi & 8 & 1 & 8 \\
\hline 3 & Rumah makan/restoran & 8 & 2 & 16 \\
\hline 4 & Sarana informasi & 8 & 2 & 16 \\
\hline 5 & Sarana kesehatan & 8 & 2 & 16 \\
\hline 6 & Sarana kebersihan & 8 & 3 & 24 \\
\hline 7 & Sarana keamanan & 8 & 2 & 16 \\
\hline 8 & Sarana hiburan & 8 & 2 & 16 \\
\hline \multicolumn{2}{r}{ Jumlah } & & 18 & 144 \\
\hline \multicolumn{2}{r}{ Mean } & & & Sumber: Hasil Penelitian, 2011
\end{tabular}

Tabel 5. Pembobotan Potensi Aksesibilitas

\begin{tabular}{clccc}
\hline No & \multicolumn{1}{c}{ Parameter } & Bobot & Harkat & Total Bobot \\
\hline 1 & Kondisi jalan & 5 & 3 & 15 \\
\hline 2 & Jenis kendaraan & 5 & 3 & 15 \\
\hline 3 & Jarak terhadap jaringan transportasi & 5 & 2 & 10 \\
\hline 4 & Waktu tempuh & 5 & 3 & 15 \\
\hline 5 & Biaya transportasi & 5 & 4 & 20 \\
\hline \multicolumn{2}{c}{ Jumlah } & & 15 & 75 \\
\hline \multicolumn{2}{r}{ Mean } & & 15 \\
\hline
\end{tabular}

Sumber: Hasil Penelitian, 2011

Tabel 6. Matriks Analisis SWOT Pengembangan Pariwisata Kawasan Situ Gede

\section{Kekuatan/Strength (S)}

1. Atraksi wisata kawasan Situ Gede berpotensi tinggi/sangat mendukung terhadap kepari-wisataan (nilai harkat 5)

2. Kawasan Situ Gede memiliki potensi daya tarik wisata yang beragam (nilai harkat 5)

3. Wisata alam dan budaya adalah potensi daya tarik yang paling unik di kawasan Situ Gede (nilai harkat 5)

4. Cinderamata tersedia beragam di lokasi objek wisata (nilai harkat 5)

5. Event wisata yang diselenggarakan beragam (nilai harkat 4 )

6. Masyarakat bersikap ramah dan partisipatif dengan menyelenggarakan pertunjukkan seni sehingga mendukung terhadap kemajuan wisata dan menciptakan lingkungan sosial yang kondusif bagi pengembangan pariwisata (nilai harkat 4)
Kelemahan/Weakness (W)

1. Tidak ada jenis tradisi adat istiadat (nilai harkat 1)

2. Sarana akomodasi buruk karena tidak tersedia penginapan (nilai harkat 1)

3. Sarana rumah makan, informasi, kesehatan, keamanan, dan saran hiburan kurang baik (nilai harkat 2)

4. Aksesibilitas belum berada pada kondisi optimal sehingga kurang memudahkan wisatawan untuk sampai di tempat wisata (nilai harkat 3)

5. Lokasi objek wisata tidak dilalui langsung oleh kendaraan umum sehingga cukup menyulitkan para pengunjung

6. Keterbatasan dana untuk pengembangan objek wisata

7. Promosi kepariwisataan belum dilaksanakan dengan baik dari segi objek, daya tarik maupun atraksi wisata

8. Sumber daya manusia kepariwisataan masih terbatas terutama dari segi 
7. Ketersediaan sarana air bersih di lokasi objek wisata tergolong baik (nilai harkat

4)

\section{Peluang/Opportunity $(\mathrm{O})$}

kuantitas

1. Objek wisata satu-satunya yang dikelola oleh pemerintah Kota Tasikmalaya

2. Terbukanya kesempatan untuk mengem-bangkan usaha jasa dan sarana penunjang pariwisata

3. Situasi dan kondisi yang relatif kondusif memungkinkan wisatawan untuk menikmati objek wisata.

4. SDM yang ada baik dari pengelola maupun masyarakat sekitar memiliki keinginan untuk mamajukan pariwisata di kawasan Situ Gede.

Melakukan promosi dan pemasaran pada wilayah-wilayah yang merupakan potensi pasar wisata yang cukup tinggi. Melibatkan peran serta swasta untuk menanggulangi keterbatasan dana dalam pengembangan pariwisata. Meningkatkan peran serta masyarakat dengan mengoptimalkan fungsi Kelompok Penggerak Pariwisata (KOMPEPAR). Menyebarluaskan informasi kepariwisataan melalui optimalisasi website internet yang dimiliki oleh pemerintah daerah.

\section{Kelemahan - Ancaman (WT)}

Pembangunan sarana prasarana penunjang pariwisata dan menyediakan fasilitas pariwisata yang beragam. Memperbaiki aksesibilitas menuju objek wisata. Dilakukan kerjasama dengan investor untuk meningkatkan pengembangan kawasan Situ Gede sebagai objek wisata. Dalam menanggulangi penyusutan jumlah kunjungan wisatawan, perlu dilakukan promosi dan pemasaran tepat sasaran. Meningkatkan kuantitas dan kualitas sumber daya manusia dalam bidang pariwisata. Memberikan penyuluhan kepada para pelaku pariwisata baik itu di
Ancaman/Threat (T)

1. Adanya daya tarik dan pengelolaan objek wisata lain yang lebih baik

2. Adanya potensi daya tarik yang mempunyai sifat kemiripan dengan daerah lain

3. Adanya persaingan yang ketat antar objek wisata dalam menarik wisatawan

4. Belum ada investor yang ingin berinvestasi di kawasan Situ Gede

5. Masuknya pengaruh budaya negatif dari luar dan terjadi interaksi antar masyarakat lokal dan wisatawan global

Sumber: Hasil Penelitian, 2011

kalangan pemerintah, tenaga kerja pariwisata maupun masyarakat sekitar. Melibatkan masyarakat dalam pengembangan pariwisata dari tahap perencanaan sampai tahap pengawasan.

Berdasarkan hasil analisis SWOT di atas, maka strategi yang dapat dilakukan untuk mengembangkan pariwisata di kawasan Situ Gede, poin terpentingnya adalah sebagai berikut: 1) Mengembangkan potensi objek wisata yang dimiliki Kawasan Situ Gede seperti adat istiadat, wisata ziarah, dan eventevent wisata. 2) Menambah keragaman atraksi wisata dengan mengadopsi kemenarikan objek wisata sejenis lainnya yang lebih maju, misalnya dengan menambah wahana outbond. 3) Memperbaiki kualitas aksesibilitas dan meningkatkan fasilitas wisata yang terdiri dari sarana informasi dan keamanan.

\section{SIMPULAN}

Potensi pariwisata kawasan Situ Gede adalah sebagai berikut: Aspek atraksi wisata, berdasarkan hasil pembobotan kawasan Situ Gede memperoleh total bobot 203 dengan mean atau rata-rata 29 , sehingga dengan 
demikian kawasan ini termasuk dalam kategori potensi tinggi/sangat mendukung. Aspek sarana dan prasarana, hasil yang didapat dari pembobotan kawasan Situ Gede memperoleh total bobot 144 dengan ratarata 18. Dengan demikian kawasan ini termasuk kategori potensi rendah/kurang mendukung dalam sarana dan prasarana.

Aspek Aksesibilitas, Berdasarkan pada hasil pembobotan kawasan Situ Gede memperoleh total bobot 75 dan rata-rata 15, sehingga kawasan ini termasuk dalam kategori potensi sedang atau cukup mendukung. Kendala pengembangan kawasan Situ Gede, Berdasarkan hasil teknik analisis persentase hampir seluruhnya kesulitan yang dirasakan wisatawan menuju objek wisata disebabkan oleh jalannya yang rusak, belum optimalnya pada situasai keamanan, ketersediaan sarana keamanan dan sarana informasi. Tanggapan wisatawan terhadap ketersediaan sarana kesehatan di lokasi objek wisata sebagian besar menyatakan tidak memadai. Hampir setengah dari responden wisatawan menyatakan perlu pembenahan dan peningkatan objek wisata terutama pada keragaman objek wisata dan sarana prasarana.

Strategi

pengembangan pariwisata yang perlu dilakukan berdasarkan analisis SWOT adalah mengembangkan potensi objek wisata yang dimiliki Kawasan Situ Gede seperti adat istiadat, wisata ziarah, dan eventevent wisata. Menambah keragaman atraksi wisata dengan mengadopsi kemenarikan objek wisata sejenis lainnya yang lebih maju, misalnya dengan menambah wahana outbond. Memperbaiki kualitas aksesibilitas dan meningkatkan fasilitas wisata yang terdiri dari sarana informasi dan keamanan.

\section{REKOMENDASI}

Adapun rekomendasi yang dapat diberikan dari hasil penelitian ini diantaranya adalah meningkatkan koordinasi dengan berbagai sektor dalam berbagai tahapan mulai dari perencanaan, pelaksanaan, dan pengawasan, baik itu sektor yang terdapat di pemerintahan, industri pariwisata, masyarakat, dan pihak-pihak terkait lainnya.

\section{DAFTAR PUSTAKA}

Arikunto, S. (1990). Prosedur Penelitian Suatu Pendekatan Praktik. Jakarta: Rineka Cipta.

Damanik, J., H. F. Weber. (2006). Perencanaan Ekowisata dari Teori ke Aplikasi. Yogyakarta: Andi.

Nuryeti. (2006). Metode Penelitian Pendidikan. Bandung: A Ifabeta. 
146 Gea. Jurnal Pendidikan Geografi, Volume 18, Nomor 2, Oktober 2018.

Peraturan Walikota No. 9 tahun 2006 tentang pemanfaatan sumber daya alam di objek daya tarik wisata Situ Gede.

Pitana, I. Gde., Putu G. Gayatri. (2005). Sosiologi Pariwisata. Yogyakarta: Andi.

Rencana Tata Ruang Wilayah

Provinsi Tahun 2002-2010.

(Online) Tersedia:

http://jdih.tasikmalayakota.go.id diakses pada 3 Februari 2011.
Tika, Moh. Pabundu. (2005). Metode Penelitian Geografi. Jakarta: Gramedia Pustaka Utama.

Ukas, M. (2006). Manajemen Konsep Prinsip dan Aplikasi. Bandung: Agnini Bandung.

Yoeti, Oka. A. (2008). Pengantar Ilmu Pariwisata. Bandung: Angkasa. 